\title{
Altyazı Çevirisinde Teknoloji Destekli Yaratıcılık Açılımı*
}

\author{
New Venues of Creativity in Subtitling with Evolving Technologies
}

\section{Araştırma/Research}

\section{A. Şirin OKYAYUZ}

Doç. Dr., Hacettepe Üniversitesi, Edebiyat Fakültesi, Mütercim-Tercümanlık Bölümü, sirinokyayuz@hacettepe.edu.tr, ORCID ID: orcid.org/orcid.org/0000-0001-7512-2764

\section{ÖZET}

Çalışmada yaratıcı altyazı çevirisi olarak betimlenen yenilikçi bir olgu üzerinde durulmuştur. İlk bölümde altyazı çevirisine çeviribilimsel bakış açısındaki değişimler evreler hâlinde özetlenmiş, bu evrimler içinde günümüzde önemle üzerinde durulan kaynakta erişim sağlanması, herkes için tasarım, tümleşik altyazı çevirilerinin oluşturulması gibi açılımlardan da ivme alarak ortaya konan yaratıcı altyazı çevirisi olarak adlandırılabilecek açılıma odaklanılmıştır. Yaratıcılığın altyazı çevirisindeki kapsamına odaklanan bölümde ise, altyazı çevirisinde değişmeyen olgulardan söz edilmiş ve yaratııılığın nasıl ve nerede devreye girdiği anlatılmıştır. Çalışmayla benzer konularda yapılan çalışmalara örnekler verilmiş, çok disiplinli çalışmalar, teknoloji uzmanlarının, tasarım uzmanlarının çalışmaları ve çeviribilimcilerin kısıtlı çalışmaları örneklenmiştir. Yöntemin betimlendiği bölümde altyazı çevirmeninin temel bakış açısından, uyguladığı bir yöntemin, stratejinin ne amaca hizmet edeceği veya nası bir etki yaratacağı araştırılarak bir araya getirilen derlem sunulmuştur. Derlem, internette çalışmada sözü edilen konuda bulunan örneklerden oluşmaktadır. Bulgular kısmında çalışma kapsamında yaratıcı altyazı çevirisinin beş açılımı olarak nitelendirilen sessel düzgüden kaynaklanan etkinin yansıtımı, kaynaktaki vurguların iletimi, ek bilgi iletimi, alımlama ve eşzamanlıık, alıcı odaklıık, duygu aktarımı konuları örneklerle betimlenmiştir. Örnekler tek tek açıklanmış, bu örneklerde uygulanan altyazı çevirisi stratejilerinin ne amaca hizmet ettiği ve edebileceği konusunda görüş ve bulgular paylaşılmıştır. Tartışma ve sonuç bölümünde çalışmada sözü edilen açılımın günümüzde yaygınlığına ve ileriye yönelik potansiyeline odaklanılmıştır. Özellikle de araştırmacıların ve eğitimcilerin bu konuda üstlenmesi gerekebilecek sorumluluklara değinilmiştir.

\footnotetext{
* Çalışmanın bir kısmı Ege Üniversitesi, Mütercim-Tercümanlık Bölümü tarafından online olarak düzenlenen Çeviribilim Seminerlerinde (24-25 Nisan 2021-Microsoft Teams) sunulmuştur. Çalışma, bu sunumda sözü edilen konudan yola çıkarak özgün bir araştırma makalesi olarak kaleme alınmıştır.
} 
Anahtar Sözcükler: yaratıcı altyazı çevirisi, ayrıntılı altyazı çevirisi, kaynakta altyazı tasarımı, herkes için tasarım, tümleşik altyazı çevirisi.

\section{ABSTRACT}

The study concerns a new venue in subtitling referred to as creative subtitling in the study. In the first section the evolution of subtitling is divided into several eras from a translation studies approach; within the latest era the new venue that builds on new approaches such as accessible filmmaking, design for all and integrated subtitling are detailed, concentrating on the impact of the production of creative subtitles. In the section dealing with the scope of creativity in subtitling, the notion itself is explained with reference to the unchanging constraints and realities in subtitling research and practice, concentrating on where creativity is sought in the act. In the following section detailing similar research, examples are provided from multidisciplinary research as well as from fields such as technology and design also referencing the limited number of studies by translation studies scholars. The methodology of the study is based on the translators' approach to the phenomena, concentrating on the strategies used and the purpose and impact of the strategies in the product. The corpus complied through material accessible on the internet is used to provide the examples. In the section detailing the findings these examples are grouped into headings such as reflecting the intended effect of the audial channel, relaying stress and intonation, transferring additional information, reception and simultaneity, reflecting feelings in accordance with receiver profiles. The examples are explained with reference to the purpose behind the use of the specific strategies and observations and insight have also been provided. In the discussion and conclusion, the current situation in this new venue of creative subtitling is discussed and future possibilities are also presented. The responsibilities that fall to researchers, subtitlers and trainers alike are also outlined.

Keywords: creative subtitling, subtitling for the Deaf and hard-of-hearing, accessible filmmaking, design for all, integrated subtitling.

\section{Altyazı Çevirisine Bakış Açısında Değiş̧iklikler}

Altyazı çevirisi edimine gerek uygulayıcıların gerekse araştırmacıların bakış açıları çeviribilim içindeki paradigma değişiklikleri ve teknolojinin gelişimi ile zaman içinde evrilmiştir (Diaz-Cintas vd., 2010). İlk başta yoğunlukla dillerarası bir edim olarak uygulanan altyazı çevirisine dilsel açıdan yaklaşılmış ve dillerarası çeviri yaklaşımlarında benimsenen kaynağa sadakat olgusu öncelenmiştir. Buna ek olarak, çoğunlukla karakterlerin diyaloglarına odaklanan araştırmalar görülmüştür.

Bir sonraki evre ise hızla gerçekleşmiş, özellikle de diliçi altyazı çevirisi ve Sağır ve işitme engelliler için altyazı çevirisinin (ayrıntılı altyazı çevirisinin) dünyada uygulamasının yaygınlaşmasıyla sessel düzgünün neleri içerdiği konusunda vurgu değişmiştir. Bu aşamada sessel düzgüdeki ses efektlerinin çevirisi, dış seslerin, kafa seslerinin, sesletim şekillerinin çevirisi ve benzeri üzerinde daha fazla durulmaya başlanmıştır.

Üçüncü evrede ise vurgu sessel düzgünün görsel düzgüyle bütünleşik olarak anlamlı bir 'tek ürün' olarak sunulması konusundadır. Farklı ülkelerdeki uygulamalar çerçevesinde, burada sözü edilen evrelerin tarihleri değişkenlik göstermektedir. Ancak, bu evreleri kesin çizgilerle ayrıştırılabilir olarak düşünmek yanlış olacaktır. Her evrede 
gerek uygulayıcılar gerekse araştırmacılar bütün sessel düzgü kapsamını düşünmüştür; ancak özellikle araştırmalarda vurgu belli bir eksen üzerinde olmuştur (açıklamalar için bkz. Jankowska \& Szarkowska 2015; Okyayuz, 2016, Okyayuz \& Kaya, 2017a).

Sağır ve işitme engelliler için yapılan diliçi ve dillerarası altyazı çevirisi (ayrıntılı altyazı çevirisi) ise farklı düşünce tarzlarının öncellenmesine neden olmuştur. Dillerarası altyazı çevirisi daha yoğun olarak yapılan ve araştırılan bir edim iken, dilsel çeviri zorlukları, ürünün görselinden kaynaklanan çeviri sorunları ve çevirmenlerin bu kısıtlı çeviri türü diye adlandırılan türdeki seçimleri daha merkezi bir konu olmuştur. Alıcıların profillerinin değiştiği Sağır ve işitme engelliler için diliçi ve dillerarası altyazı çevirisi ediminin yoğunluğu arttığında, bilişsel araştırmalar ve bunun ötesinde algılama, alımlama çalışmaları yoğunluk kazanmıştır. Bu açılımlar ise altyazı çevirisinin neleri kapsadığı ya da neleri kapsaması gerektiği, daha doğrusu altyazı çevirisinde nelere dikkat edileceği ve hangi yöntemlerle uygulanacağı konusunda yeni veriler ortaya konulmasına vesile olmuştur (Neves, 2008; Delabastita, 1989; Chiaro, 2009; Perego, 2016). Teknolojideki gelişimler de bu son açılımı desteklemiş ve genişletmiştir (Strapparava vd., 2007, s. 1724).

Söz konusu makale, bu evrimler içinde günümüzde önemle üzerinde durulan kaynakta erişim sağlanması, (İng. accessible film making) (bkz. Romero-Fresco, 2013, 2019; Stephanidis, 2001); herkes için tasarım (İng. design for all) (Persson vd., 2015; Lazar \& Stein, 2017), tümleşik altyazı çevirilerinin (İng. integrated subtitles) (Black, 2020; Brewer vd., 2014; Brown vd., 2015; Butler, 2016) oluşturulması gibi açılımlardan da ivme alarak ortaya konan yaratıcı altyazı çevirisi olarak adlandırılabilecek açılıma odaklanmaktadır. Bu açılımın neleri içerdiğini, nasıl bir felsefe ve yaklaşım benimsediğini örneklerle irdelemeyi amaçlayan çalışmada, yaratıcılık gibi özünde kısıtı olmayan soyut bir kavram (yaklaşım), alandaki çevirmenlere olası seçenekleri somut örnekler üzerinden belli başlıklar altında sunmayı hedeflemektedir.

\subsection{Yaratıcılığın Altyazı Çevirisindeki Kapsamına Üstsel Bir Bakış}

Çalışma kapsamında yaratıcılık olarak adlandırılan olguyla tam olarak neyin ifade edildiğini açıklamak gerekir. Genelde çeviri ve yaratıcılık kavramları aynı bağlamda kullanıldığında, kaynak ürünü öngörülmeyen bir şekilde ele almak ya da kaynaktan uzaklaşarak bir erek metin ortaya koymak gibi uygulamalar düşünülebilmektedir. Hatta çevirmenlerin çoğunun aklına gelmeyecek çeviri stratejileri ile metne yaklaşmak bile düşünülebilir (bkz. Okyayuz \& Kaya 2017b). Ancak, altyazı çevirisi bağlamında sözü edilecek yaratıcılık yaklaşımında farklı açılımlara değinilmektedir. Altyazı çevirisinde bugüne kadar süregelen ve değişmeyenlerden de söz etmek gerekecektir, zira yaratıcılık bu değişmeyen gerçekleri de dikkate alarak tasarlanacaktır.

Birincisi, bu bölümde tanımlanan ve bulgular başlığı altında örneklerle sunulan altyazı çevirisi eklentili ürünler dillerarası ve diliçi çevirileri içermektedir. Zira Sağır ve işitme engelliler için altyazı da dâhil olmak üzere tüm altyazı çevirisi türleri dillerarası ve diliçi biçiminde de yapılabilmektedir. 
İkincisi, altyazı çevirisi kapsamında ele alınan bazı açılımlar, altyazı çevirisi ile benzeşen (ve ayrışan) özellikleri olan üstyazı çevirisinde daha kısıtlı bir uygulaması olabilecek olsa bile düşünülebilecektir ('üstyazı çevirisi' için bkz. Okyayuz, 2019).

Üçüncüsü, örneklenen tüm uygulamalar tek bir bağlamda geçerliymiş gibi sunulmuş olsa da aslında bazı örnekler ürünle tümleşik (İng. integrated) altyazılara, bazıları kaynakta eklenen altyazılara (ing. accessible filmmaking) bazıları ise sonradan eklenti olarak (İng. subtitling proper) ürüne ek bir görsel düzgü olarak eklenen altyazılara örnektir. Bu da birkaç konuyu gündeme getirir. Illk olarak, çevirmen altyazı çevirisi yapılacak kaynak ürüne ne aşamada erişmiştir, engelsiz erişim süreci ürün oluşturulurken mi başlamıştır sonradan mı düşünülmüştür gibi konuları tartmak gerekir. Ayrıca, söz edilen çevirmen kaynak ürüne 'teknolojik olarak' ne kadar müdahale edebilmiştir? Elindeki teknik altyapı ve kılavuz nedir? Buna ek olarak bir de işverenin teknolojik olanaklarından söz edilmesi gerekir. Çevirmen çok yaratıcı bir altyazı sunabilir, ancak bunu yayımlayacak kanalda bunu açık altyazı ya da kapalı altyazı olarak sunacak altyapı var mıdır?

Dördüncü olarak da burada sunulan bazı örnekler canlı altyazı türünde de uygulanabilirken bazıları üzerinde zaman harcanması tasarımlar gerektirdiğinden bu altyazı çevirisi türünde geçerli olmayacaktır ('canlı altyazı çevirisi' için bkz. RomeroFresco, 2011). Hatta, çoğu öneri kayıttan yayınlar için çok daha uygundur, ancak öngörülü bir şekilde hareket ederek teknoloji ilerledikçe bazılarının canlı altyazı çevirisinde de geçerli olabileceğini söylemek yanlış olmayacaktır.

Bir başka konu ise her bir altyazı çevirisi türünde bazı değişen uygulamalar olduğudur (örn. ortamdan ortama, kanaldan kanala, dilden dile). Bunu altyazı çevirisi geleneği olarak düşünebiliriz. Yenilikçi açılımlara açık olan işverenler veya ortamlar olabileceği gibi, gerek bu açılımlar teknolojik altyapıda yenilikler ve yeni çevirmen profilleri gerektirdiğinden yatırım yapılması kaçınılmaz olduğu için gerekse alıcı kitleden bir eleştiri alma olasılığı yüzünden bu yenilikleri benimsemeyecek işverenler, kanallar da olacaktır.

Bu düşünceye ek olarak, çalışma boyunca sunulan bazı yaratıcı altyazı çevirisi örneklerinin Sağır ve işitme engellilerin sesli düzgüde iletilen bazı bilgileri algılamaktaki zorluğundan dolayı düşünüldüğü ve dolayısıyla bu kitle alıcı olarak belirlenmediyse belki de gereksiz olabileceği de öne sürülebilir. Kaynak işitseli hangi dilde olursa olsun duyan biri için gereksiz olabilecektir. Ancak, bunun aksine altyazı çevirisinde bu unsurların yansıtımının ürünü daha ilginç kılacağını ya da sessel düzgüdeki bazı unsurlara dikkat çekeceği için uygulanabileceğini de düşünenler olacaktır. Bazı duyan alııılar özellikle yaratııı bir şekilde sunulan altyazıların dikkat dağıtacağını ya da takip edilmesinin zor olacağını da düşünebilirler. Ayrıca, bu çalışma kapsamında sözü edilen yaratıcılığın çeviri dilindeki yaratıcılığın yerini tutmayacağını, yalnızca ek bir açılım olarak sunulduğunu da unutmamak gerekir.

Tüm bunlara ek olarak ilk uygulanmaya başlandığı günden beri kısıtlı bir çeviri türü (en azından sunum süresi ve uzamı bile düşünüldüğünde) olduğu kabul edilen altyazı çevirisine dair bazı gerçekler de hâlen değişmemiştir (kısıtılık ve parametrelerle 
ilgili çalışmalar ve örnekler ile ilgili bkz. ABC, 2010; Albertini \& Mayer, 2011; Baker vd., 1984; BBC, 2018; Doherty \& Kruger, 2018; Ehrlich \& Rayner, 1981; Kruger \& Steyn, 2014; Kruger vd., 2015; Media Access Australia, 2012; Perego, 2008a, 2008b). Genelde, altyazı çevirisi görsel olarak sunulan bir düzgüdür ancak son zamanlarda örnekleri görülmeye başlanan görme engelliler için sesli altyazı çevirisi uygulaması açılımını da unutmamak gerekir. Altyazı çevirisi kaynak ürünün alımlanmasına, erişilmesine izin veren, kaynak görselle bütünlüklü olarak anlamlanan bir çeviri türüdür; bu gerçek de değişmemiştir. Ayrıca altyazı çevirisindeki açılımlar teknolojik yenilikleri takip etmektedir (kimi zaman da bunlara vesile olabilmektedir). Altyazı çevirisindeki zorluklar ise uygulamanın ilk yapıldığı günden bu yana fazla değişmemiştir: örneğin, aynı sahnedeki birden fazla konuşanı belirlemek, seslerin nereden geldiğini ve duyulma oranlarını belirtmek, tekrarlanan sesleri iletmek, ses efektlerini, dış sesleri ve müziği aktarmak ve benzeri.

Çalışmada yaratıcı altyazı çevirisi açılımı olarak betimlenen yaklaşımda da çeviribilim alanının dışından uzmanlar araştırmalar yapmaktadırlar (örnekler için bkz. Rawsthorn, 2007; Rosenberg, 2007; Vy, 2012; Hong vd., 2010; Lee vd., 2006; Rashid vd., 2008; Vy \& Fels, 2009; Vy vd., 2008). Altyazı çevirisinde sözü edilen yaratıcı açılımlar ise günümüz teknolojileri gereği insan eliyle tasarlanmalı ancak çeviribilim alanında diğer alanlara kıyasla çok daha az çalışma üretilmektedir (örnekler için bkz. Diaz-Cintas, 2013; Mcclarty, 2012; Möhnle, 2020; Butler, 2017).

\section{Yöntem}

Çalışmada kullanılan yaratıcı altyazı çevirisi örnekleri internetten derlenmiş ve tasnif edilmiştir. Yukarıda verilen bilgilerden de anlaşılacağı üzere amacı yaratıcı altyazı çevirisi açıımını betimlemek ve çeviribilim açısından ele alınabilecek bir bakış açısıyla sunmak olan çalışmada, en merkezî önemde olan bulgu derlemden yola çıkarak sunulan gruplandırılmadır.

Yukarıda verilen bilgiler ışığında çerçeveyi çizdikten sonra, sözü edilen yaratıcı açılımların birkaç değişik şekilde gruplandırılması söz konusu olabileceğinden de bahsetmek gerekir.

Bu gruplama tasarımın yapıldığı ortama bağı olarak yapılabilir. Örneğin, belli yazı türlerinin kullanımı, yazı türünün kaynak girdiye uygun tasarımı gibi. İkinci olarak, altyazının ekranda konumlandırılması ve sunumu açısından ele alınabilir. Üçüncü olarak, altyazı çevirisinin fonunun tasarımından söz edilebilir. Altyazı çevirisinde diyaloglara ek sessel ve benzeri düzgünün tasarlanarak sunulmasından söz edilebilir. Bu tasarım açısından olasılıkları sunan bir gruplama olacaktır.

Bunlara ek olarak bu çalışmada sunulan örneklere kaynakta erişim sağlanabildiğinden, bir yazılımla çeviri eklendiğinde, yapılabilecekler olarak da ayrıştırılabilir. Bu da çevirmenin ürüne erişim aşamasına odaklanan bir gruplama olacaktır.

Ancak bu çalışmada örneklenen tasarımların nerede ve ne unsur için yapıldığı gibi bir bakış açısı benimsenmemiş, çevirmen bakış açısından olguya yaklaşılmıştır. Bir altyazı çevirmeninin temel bakış açısı ise her çevirmen gibi uyguladığı bir yöntemin, 
stratejinin ne amaca hizmet edeceği veya nasıl bir etki yaratacağı üzerinde olacaktır. Dolayısıyla, aşağıda belirtilen ve çalışmada benimsenen gruplama bu yaklaşımdan hareketle düzenlenmiştir. Bu yaklaşımın temelleri ise Diaz Cintas ve Rameal'in (2009) altyazı çevirisine özgülenmiş eserlerindeki sunuma dayanmaktadır. Yazarlar altyazı çevirisinin göstergebilimsel, teknik, konvansiyonel, dilsel konularını ele aldıktan sonra altyazı çevirisinde çeviriye özgü konular başıı̆ını açarak, olguya listelenen tüm açılardan bakıldığında bile çevirmen ve çeviri konularının ek bir katman/unsur olarak ele alınması gerektiğine vurgu yapmışlardır. Bu tasarımda yazarlar, çevirmenin altyazıyı oluşturan göstergebilimden tekniğe, konvansiyonlardan dile birçok unsurun üstüne, gerek belli zorlukları ve kısıtları ile başa çıkmak gerekse kaliteli altyazı çevirisi üretmek için, üzerinde durulması gereken bir açılım olduğunun altını çizerler. Bu yaklaşımdan yola çıkarak da çalışmada benzer bir bakış açısı benimsenmiştir.

Çalışmada internet üzerinden erişime açık olan örnekler derlendiğinden bu derlemle sınırlı olarak başlıklar belirlenmiştir. Uygulamada başka açılımların olacağı kuşkusuzdur; başka başlıklar çıkabileceği gibi başka örnekler de olabilecektir. Ancak, bu örnekleri kategorize etmek için erişmek bu aşamada olası değildir. Bu yaklaşımdan yola çıkarak aşağıda belirtilen açılımlar tespit edilmiştir. Örnekler gruplandırılırken ise kaynakta var olan hangi etkinin hangi amaçla altyazı çevirisinde yaratıcı bir şekilde sunulduğu sorgulanmış; her örnek bu sorunun cevabına göre tasnif edilmiş ve gruplama başlıkları belirlenebilmiştir.

Birinci açılım, işitsel düzgüde sunulan bir ögenin yazı modu ile yansıtılamayan unsurlarını da yansıtmak ve aynı etkiyi yaratabilmek için görsel düzgüde (altyazıda) tasarlamak olarak açıklanabilir. Bu da dil düzeyinde bir yaratıcılığı gerektirdiği gibi, altyazının sunuluş şeklinde de bir tasarımı gerektirecektir. Bu bağlamda sunulan örneklerde sessel düzgüden kaynaklanan etkinin yansıtımı öncelenmiştir. İkinci açılımda kaynak işitsel düzgüde ifade edilen bilginin alımlanmasını kolaylaştırmak ya da anlamını, etkiyi vurgulamak için altyazının sunuluş şeklini tasarlamaktan söz edilebilir. Bu bağlamda kaynak üründeki belli noktaları vurgulamak konusu öncelenmiştir. Üçüncü açılımda ise kaynak işitsel düzgüye ek bilgi olarak girilen unsurların tasarlanarak aktarımından söz edilebilir. Bu bağlamda ek bilgi iletimi üzerinde durulmuştur. Dördüncü açılımda ise alımlamayı kolaylaştırmak, eşzamanlı olarak sessel düzgü ve kaynağına ilişkin bazı unsurların bir arada iletilmesi için bir tasarımdan da söz edilebilir. Bu bağlamda ön planda olan unsurlar alımlama ve eşzamanlılıktır. Beşinci açılımda ise birçok farklı yöntemle alıcı odaklı bir yaklaşımla tasarım yapılmasından söz edilebilir. Bu örneklerde ise alıcı odaklılığın altı çizilmiştir. Bu bölümde kısaca tanımlanan açılımlara aşağıda örnekler verilmiş ve açıklanmıştır.

\section{Bulgular}

Yukarıda anlatılan yöntem ve yaklaşımla derlenebilen beş tür açılımdan söz edilmektedir. Bazı başlıklar altında sunulan örnekler başka başlıklara da dâhil edilebilmektedir. Örneğin, bir unsuru vurgulamak için kullanılan bir yöntem, söz edilen ögenin alımlanmasını da kolaylaştırabilecektir. Bu da görsel-işitsel ürünün görsel ve işitsel düzgüleri bütünleşik olarak sunulan ve algılanan bir ürün olmasından 
Altyazı Çevirisinde Teknoloji Destekli Yaratıcılık Açılımı*

kaynaklanmaktadır. Bu gerçeği göz ardı etmeden, seçilen örnekler altında sunuldukları kategorileri açıklamak için oldukça açık oldukları için de seçilmiştir.

\subsection{Birinci Açılım: Sessel Düzgüden Kaynaklanan Etkinin Yansıtımı}

Birinci açılım, işitsel düzgü yazı modu ile tamamıyla yansıtılamadaı̆ı için amaçlanan etkiyi yaratabilmek için görsel düzgüde (altyazıda) tasarım yapılması olarak açıklanabilir. Bu da dil düzeyinde bir yaratıcılığı gerektirdiği gibi, altyazının sunuluş şeklinde de bir tasarımı gerektirecektir.

Burada sunulacak örnek, alanda çok özgün çalışmalar sunan ve bunları akademik açıdan da inceleyen Sean Zdenek (çalışmaları için bkz. Zdenek, 2007, 2011, 2014, 2015, 2016, 2018a, 2018b, 2020) tarafından Three Musketeers (2011) filminin DVD sürümüne uygulanmış olan altyazı çevirisidir.

Klasik Üç Silahşörler kitabının uyarlaması ve filminin yeniden çevrimi olan söz konusu örnekte silahşörlerden Athos'un bardağına uyuşturucu konmuştur. Silahşörlerin karşısında yer alan Leydi De Winter ve Buckingham'ın koyduğu uyuşturucu etkisini gösterdiğinde ise Athos karakteri uyuşturucu içmiş olmanın etkisiyle sözcüklere odaklanamamakta, net işitememekte ve görememektedir, şuurunu kaybetmemek için çaba sarf ederken kimi yerde bunu başaramamaktadır.

Altyazı çevirmeninin Adobe After Effects kullanarak metne işlediği diliçi altyazılar Athos'un yaşadıklarını izleyiciye aktarmak amacıyla onun gözünden anlatılan sahnede uyuşturulmuş bir insanın algısını çağrıştırmak üzere tasarlanmıştır.

\section{Resim 1}

Ü̧̧ Silahşörler (2011) https://youtu.be/Ui22STsDLOE

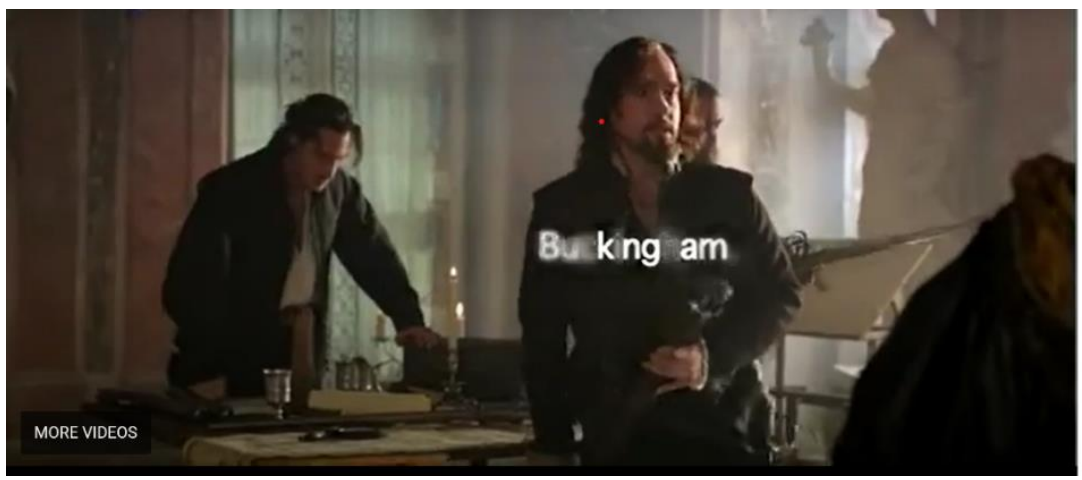

Resim 1'den anlaşılacağı üzere, altyazı çevirmeni, Athos'un uyuşturucunun etkisi altında ancak fısıldayarak ve kimi heceleri yutarak sesletebildiğini ifade etmek için altyazıda bazı harfleri silik olarak iletmiştir. "Buckingham" diye seslenen Athos karakterinin bu konuşma zorluğunu, "B.k.nh.am” şeklinde sunmuş ancak geri kalan 
harfleri bulanık da olsa vererek üründe izleyenin ne söylendiğini anlayabilmesini de sağlamıştır.

\section{Resim 2}

Üç Silahşörler (2011) https://youtu.be/Ui22STSDLOE

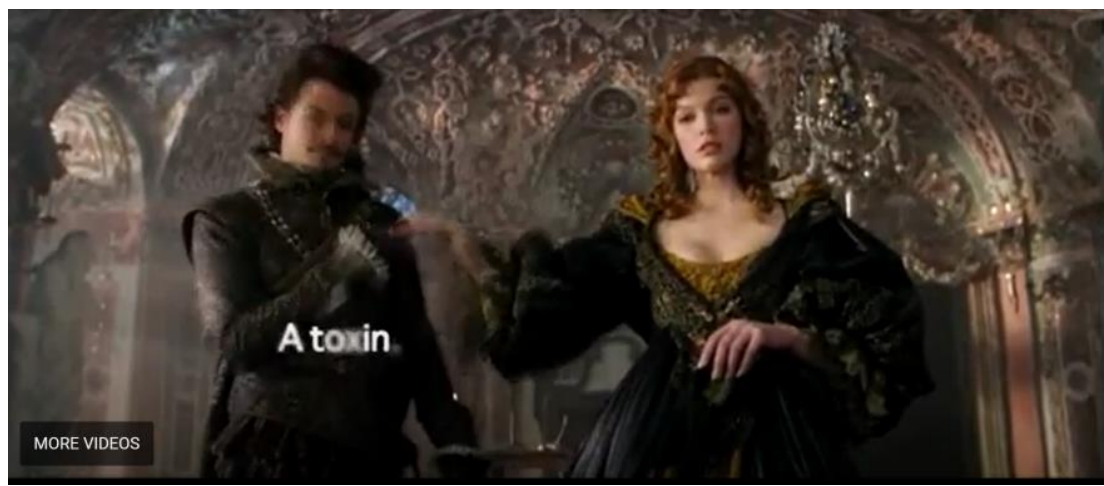

Resim 2'de sunulan örnekte altyazı çevirmeni bu sefer de Athos karakterinin duyma ve algılama zorluğunu betimlemek için silik harfleri içeren sözcükler kullanmıştır. Ancak, bu bağlamda da sözcük ilk ekranda belirişinde açıkça görülür bir şekilde yazılmış ve sonrasında bazı harfler silikleştirilmiştir. Yine alıcının sözcüğü tanımasına, ancak sessel düzgüdeki etkinin de aktarılmasına izin verilmiştir.

\section{Resim 3}

ÜçS Silahşörler (2011) https://youtu.be/Ui22STsDLOE

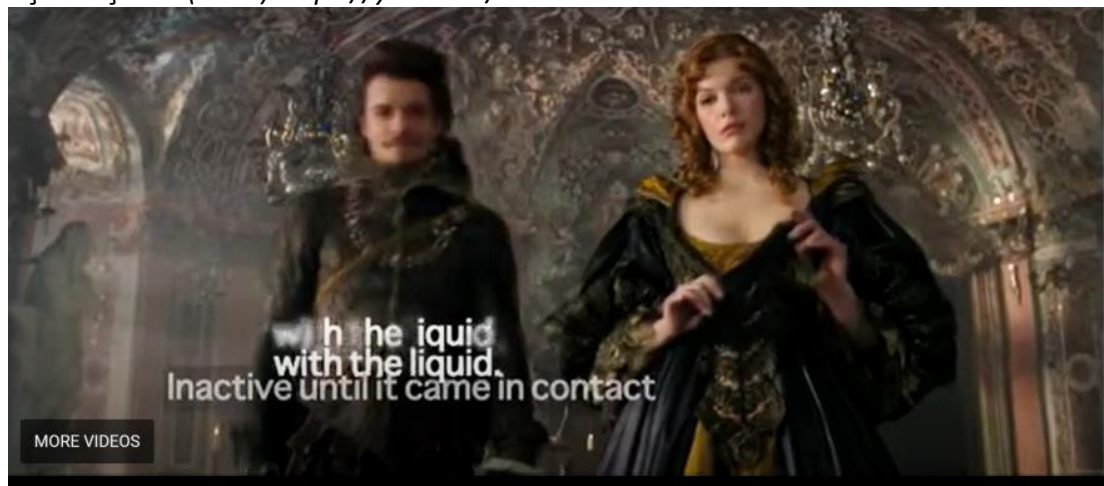

Bu kategori altında Zdenek'ten alınan son örnekte (Resim 3) Athos karakterinin bayılmaya başladığı için eko olarak (yansımalı) duyduğu seslerdeki etkiyi yaratmak için Athos'un algısında yankılanan tümce iki defa ekrana yansıtılmış, ancak bir sürümü silikleştirmiştir. Böylece etkiyi iletirken alıcıya ek bir okuma yükü getirilmemiştir.

$\mathrm{Bu}$ kategori altında sesletim ve algılama şeklinin tasarıma yansıtılması mantığından hareketle daha birçok örnek verilebilir. 


\section{Resim 4}

Night Watch (2004), https://images.app.goo.gl/4QJThAL8G1rBkgS16

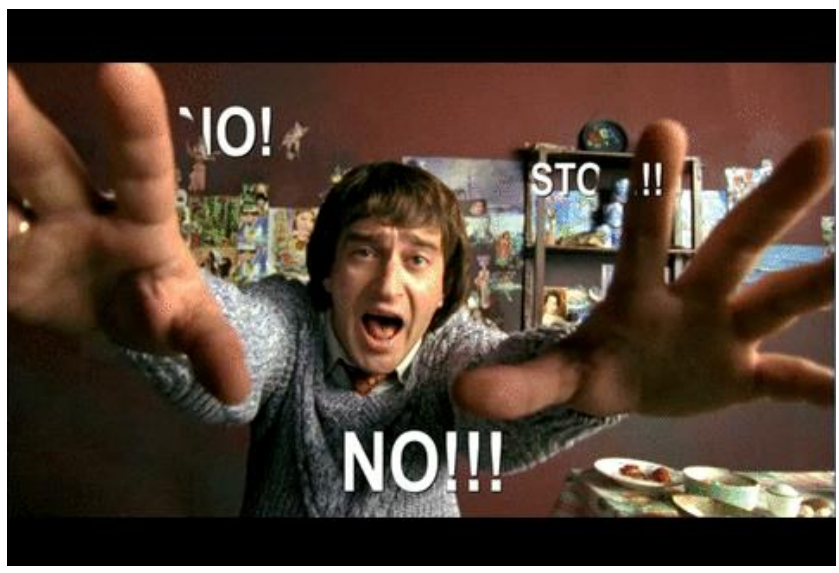

Resim 4'te örneklendiği üzere, nida ve haykırışların altyazı satırından ayrılarak görsele entegre edilmesi ya da daha çarpıcı puntolarla ve fontlarla yazılması söz konusu olabilmektedir. Yukarıda verilen kareden de anlaşılacağı gibi çizgi roman geleneğinde nida ve efektlerin yansıtımına benzeyen bu yaklaşım hem duyguyu hem de etkiyi yaratmak için verimli olabilecektir. Ayrıca, bu uygulamaya animasyon da eklenebilmektedir.

Yine Zdenek'ten bir örnekte görsel-işitsel üründe etten kemikten bir kadın olarak algılanan bir karakterin bir repliğinde sesinin statik varmış gibi kesilmesi ve görüntüsünün anında gidip gelmesi, karşısındaki karaktere bu 'kadının' bir simülasyon olduğu belli edilir. Hem görseldeki titreşimle hem de işitseldeki kesiklikle ortaya konan bu unsuru çevirisine yansıtan çevirmen bu sefer de kadının konuştuğu Thelonius karakterinin gözünden ve algısından olaya yaklaşarak karakteri bir kadın olarak algıladığı süre içinde belli bir altyazı formatı kullanırken bir simülasyon (yapay zekâ ürünü) 
olduğunu anladığı andan itibaren başka bir altyazı formatı kullanarak bu farklılaşmaya vurgu yapmıştır.

\section{Resim 5}

The 100, Blood Must Have Blood, Part 2, 2015.

https://kairos.technorhetoric.net/23.1/topoi/zdenek/typography.html

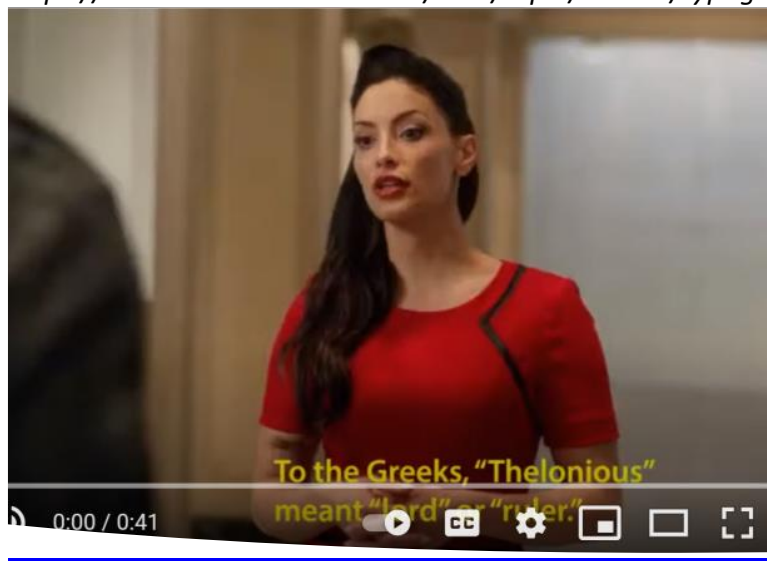

\section{Resim 6}

The 100, Blood Must Have Blood, Part 2, 2015.

https://kairos.technorhetoric.net/23.1/topoi/zdenek/typography.html

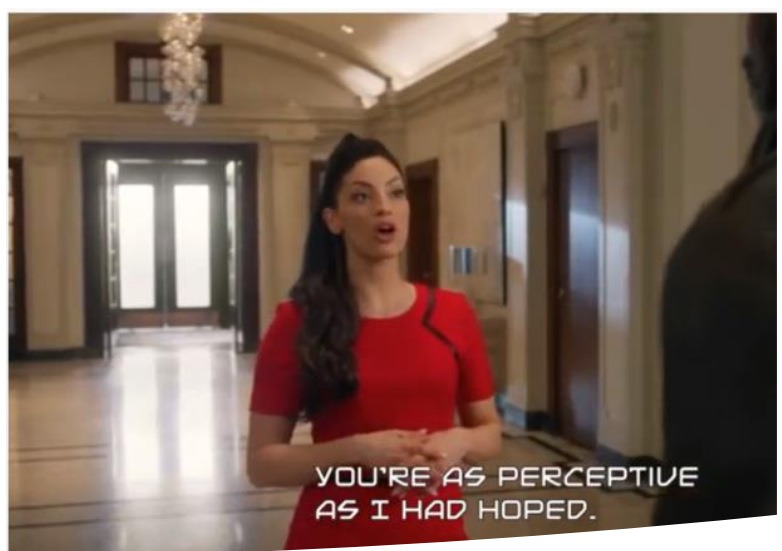

Yukarıdaki birinci resimde (Resim 5) insan olduğu var sayılan karakterin repliği diğer tüm karakter replikleri gibi sarıyla sunulmuşken, yapay zekâ ürünü olduğu anlaşıldığı andan itibaren bu durumu çağrıştıracak bir yazı türüyle ve beyazla verilmeye başlanmıştır (Resim 6). Thelonius karakterinin algısı yansıtılırken bir yandan da karakterin bir özelliği de vurgulanmıştır. 


\section{2. İkinci Açılım: Belli Noktaları Vurgulamak}

İkinci açılım, kaynak işitsel düzgüde ifade edilen bilginin alımlanmasını kolaylaştırmak ya da anlamını, etkiyi vurgulamak amacıyla altyazının sunuluş şeklini tasarlamayı içerir. Bu bağlamda verilen örnek BBC Newsnight programından alınmıştır. Birleşik Krallık için çok önemli olan gündemdeki bir konudan, 'Brexit'ten söz eden şahsın sözlü dilde belli vurgularla verdiği kısımlara bir tasarım yapılmış, ayrıca anahtar sözcükler ve konuda önemli bulunan noktalar da belli stratejilerle verilmiştir.

\section{Resim 7}

BBC Newsnight. https://vimeo.com/283470586

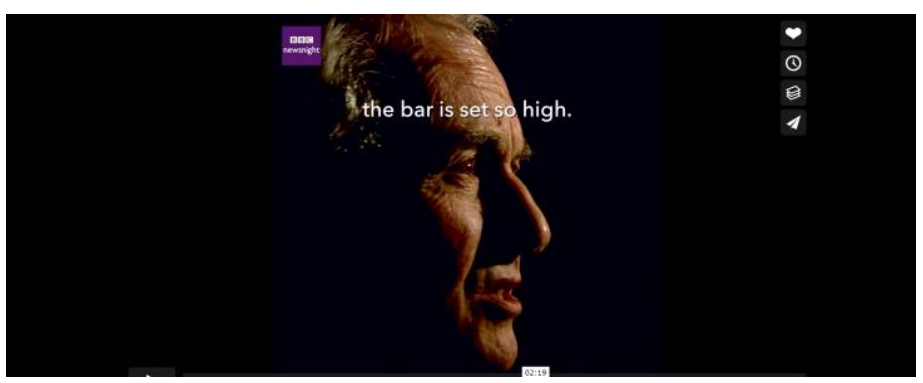

Resim 7'de görüldüğü şekilde, Newsnight boyunca genellikle ekran altında verilen altyazılar, Avrupa Birliğindeki çıtanın yüksekliğinden söz eden konuşmacının 'çıta çok yüksektir’ yorumunu vurgulamak için yükseğe, ekran üstüne doğru kaydırılmaktadır.

\section{Resim 8}

BBC Newsnight. https://vimeo.com/283470586

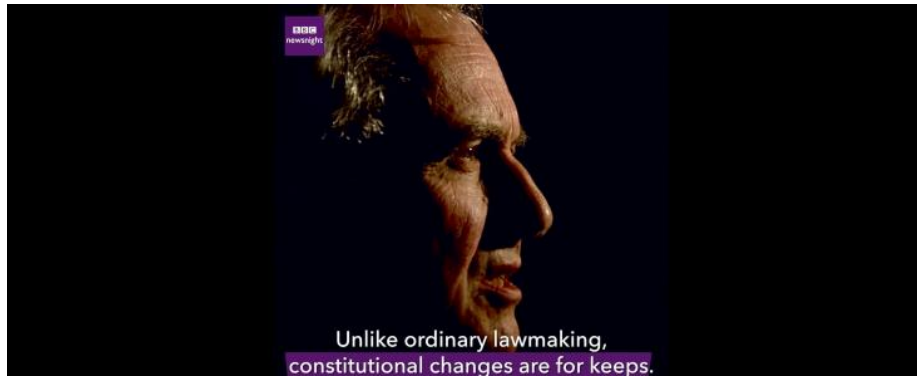

Resim 8'de görülebileceği gibi, konuşmacının altını çizerek vurguladığı önemli anahtar sözcükler altyazıda mor fonla ön plana çıkarılmaktadır. Ayrıca, mor fon siyah zemin üzerine bindirildiğinden ve yazılar beyaz olduğundan kontrast oluşturulmakta ve okumada güçlük çekilmemektedir. 


\section{Resim 9}

BBC Newsnight. https://vimeo.com/283470586

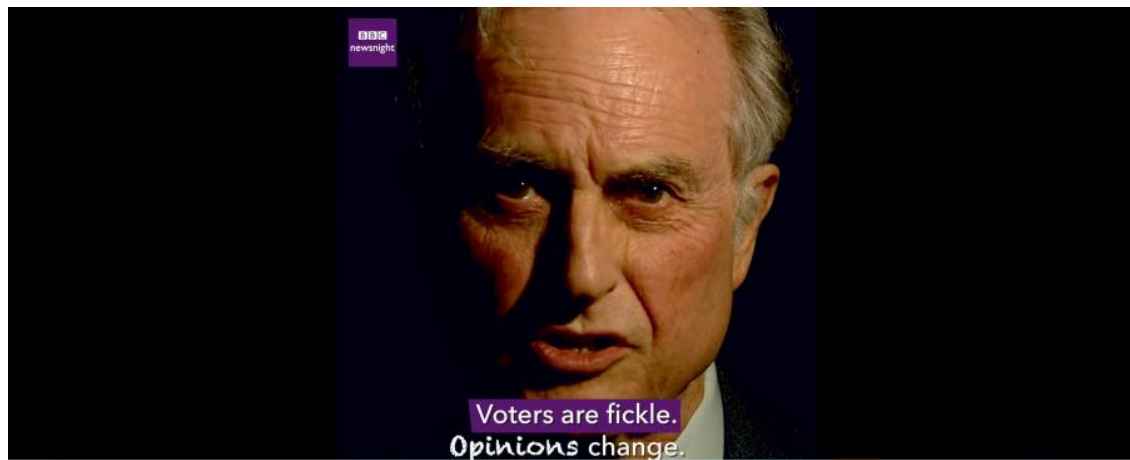

Resim 9'da sunulan repliklerde konuşmacı 'görüşlerin değiştiğine' vurgu yapmaktadır. Bu örnekte altyazıda 'görüşler değişir' (opinions change) ifadesindeki görüş (opinion) sözcüğü hızla değişen beş ayrı fontla yazılarak bu 'değişim' görselleştirilmektedir. Yazının yeri değişmediğinden alımlamada bir sorun yaşanmamaktadır.

\section{Resim 10}

BBC Newsnight. https://vimeo.com/283470586

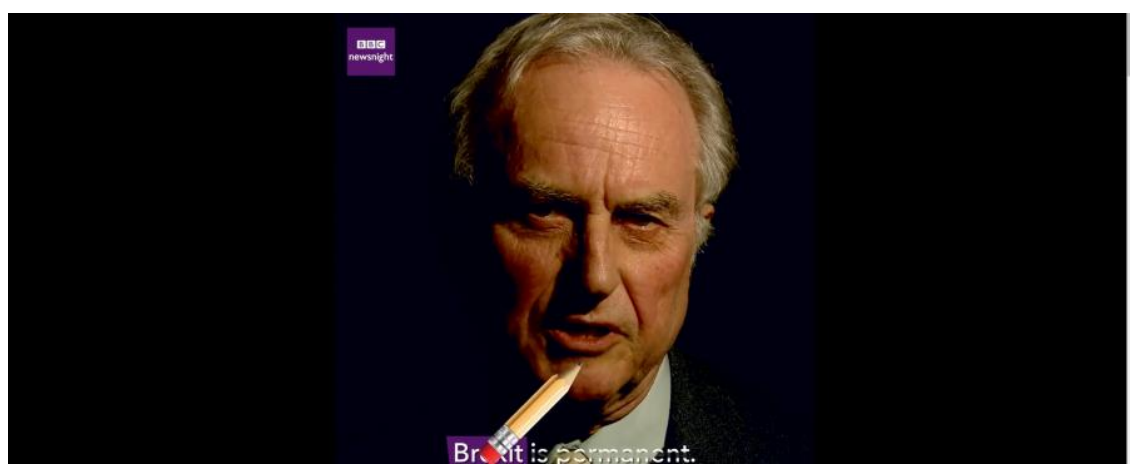

İkinci kategori altındaki son örnekte (Resim 10), Brexit'in halk tarafından alınan iyi düşünülerek karar verilmesi gereken kalıcı bir konu olduğunu ortaya koyan konuşmacının sesiyle vurguladığı kalıcılığı görselde vurgulamak için altyazıdaki 'permanent' (kalıcı) sözcüğü bir silgiyle silinerek Brexit bir kere yaşanırsa geri dönüşü olmayacağına vurgu yapılmaktadır. Altyazının bir kısmı silgi ile silinmeden alımlamayı zorlamayacak uzunlukta ekranda kalmaktadır, böylelikle konu vurgulanmakta ve altyazının okunması zorlaşmamaktadır. 


\section{3. Üçüncü Açılım: Ek Bilgi İletimi}

Üçüncü açılım, kaynak işitsel düzgüye ek bilgi olarak girilen unsurların tasarlanarak aktarımını kapsar. Burada en belirgin örneklerden biri hangi karakterin konuştuğunun, Sağır ve işitme engelliler başta olmak üzere alıcılar tarafından algılanması için karakter isimleri eklenmesi geleneğidir. Günümüz teknolojileri ile bu gelenekte de değişiklik yapılabilmektedir.

\section{Resim 11}

Demo Video: Creative subtitles - design and mechanics.

https://images.app.goo.gl/CfKfeLVZjeZh27cMA; $h$ ttps://youtu.be/4pH9j6hweDY

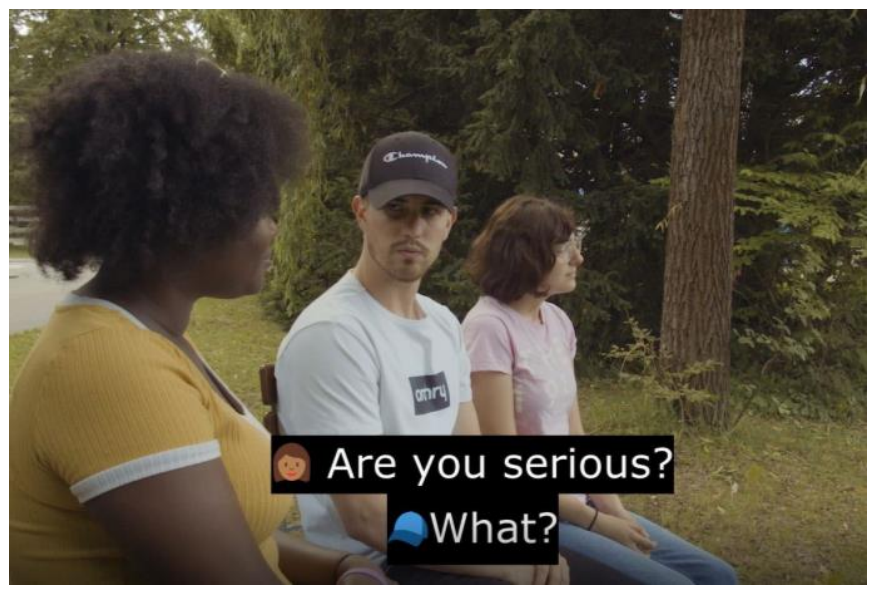

Resim 11'de sunulan örnekten de anlaşılacağı üzere, karakter isimlerini okuma ve karakterleri isimleri ile eşleme zorluğunu ortadan kaldıran, buna ek olarak da genelde karakter isimlerinin yazılması ile bir uzam kaplandığından (karakter sayısı) bu uzamda yer açıp altyazıya daha fazla yer bırakan emoji ile karakter belirtme açılımı oldukça verimli bir açılımdır.

Melina Möhnle'nin (2020) altyazı çevirisi açılımından sunulan örnek özünde Sağır ve işitme engelliler için kayıttan yayınlarda öngörülmüştür, ancak bu uygulamanın eğer altyapı sağlanırsa canlı altyazı çevirisinde bile kullanılabileceği açıktır. Bu bağlamda bazı zorluklar da olabilecektir, bir giyim eşyası ile tanımlanan karakterin üründe üstünü değiştirmesi, fiziksel özellikleri benzeyen karakterlere benzer olmayan (ayrıştırılabilen) emojiler kullanılması ve benzeri. Ancak bu açılım yine de okuma hızını arttırdığı, algılamayı kolaylaştırdığı ve uzamdan tasarruf edilmesini sağladığı için kullanımı düşünülmesi gereken bir yeniliktir.

\subsection{Dördüncü Açılım: Alımlama ve Eşzamanlılık}

Dördüncü açılım, alımlamayı kolaylaştırmak için yapılır ve eşzamanlı olarak sessel düzgü(ler) ve kaynağına ilişkin bazı unsurların bir arada iletilmesi için bir tasarım yapılmasını gerektirir. Bu başlık altındaki en bariz örnekler sesin yansıttığı unsurun betimlenmesi olarak düşünülebilir. 
Örneğin aşağıdaki karede olduğu gibi (Resim 12) bir karakterin cep telefonuna gelen mesajı içinden (kafa sesi ile) okuması.

\section{Resim 12}

Sherlock (2010-2017). https://iheartsubtitles.wordpress.com/tag/creative-subtitling/

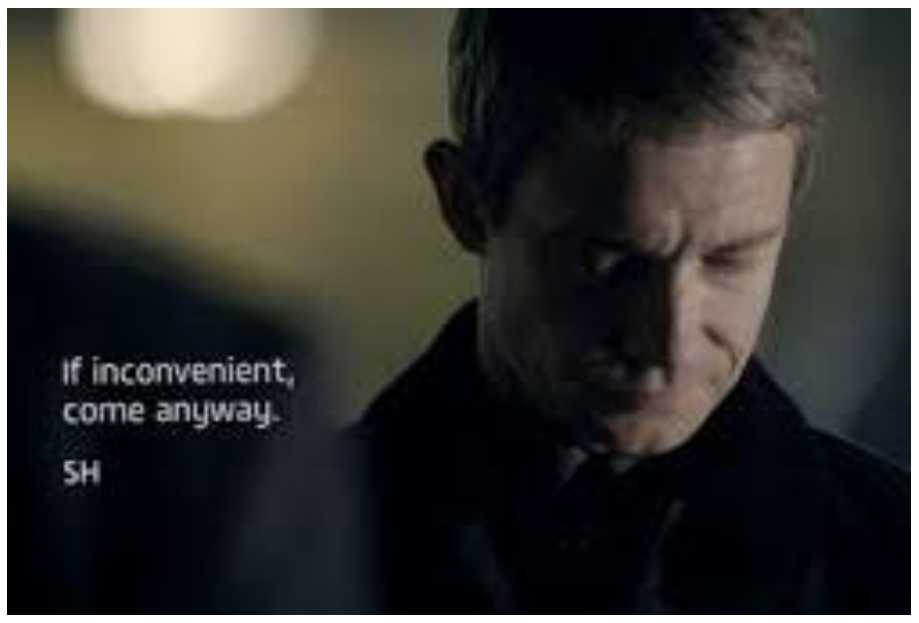

Ya da aşağıdaki karede (Resim 13) örneklendiği şekilde bir karakterin sesli bir şekilde yazılı bir metni okuması.

\section{Resim 13}

Demo Video Creative subtitles- design and mechanics. https://lab.irt.de/creative-subtitles-designand-mechanics/

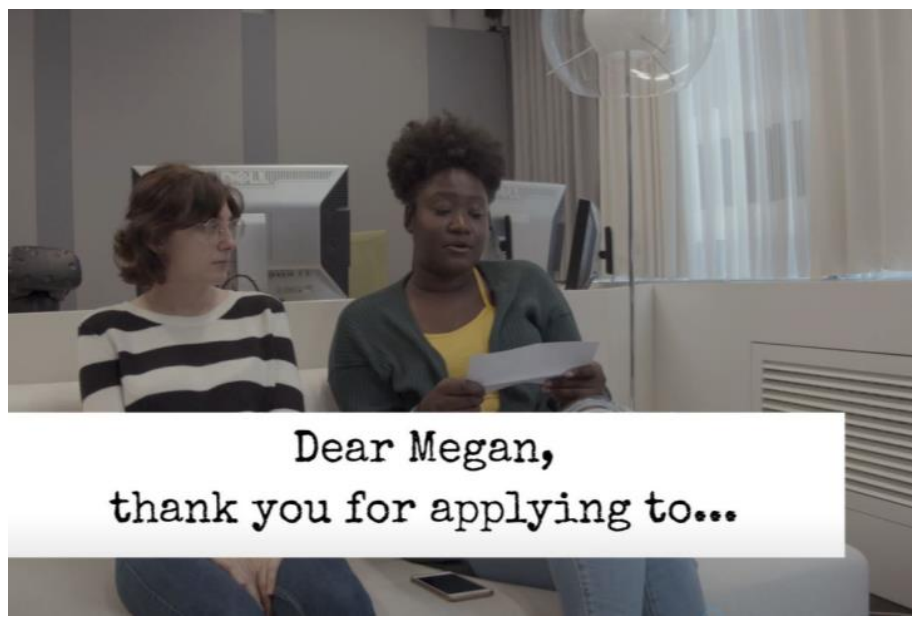

Metinlerin sunumuna ek olarak henüz çok fazla altyazı örneği görülmeyen (Resim 14) ancak bir açılım olarak göz önünde bulundurulması gereken kafa sesi, düşünce sesinin yansıtımı da bu başlık altında ele alınabilir. 


\section{Resim 14}

Sherlock (2010-2017). https://iheartsubtitles.wordpress.com/tag/creative-subtitling/

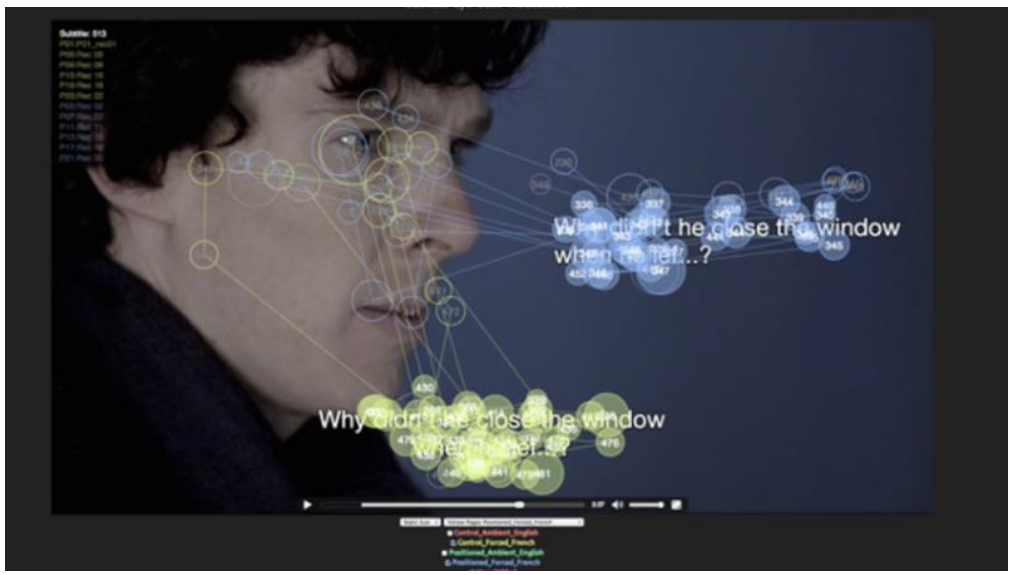

Altyazı çevirisinde farklı sunumlarla ek bir açıklama gerektirmeden dillendirilen kaynak metne örneklendiği şekilde gönderme yapılabilmektedir.

Eşzamanlı olarak iki sessel düzgünün yansıtımı da bu başlık altında ele alınabilir. Aşağıda sunulan örnekte bir yandan konuşmaların geçtiği bir sessel düzgü bulunmaktadır; diğer yandan denek olarak kullanılan bir karakterin kalp monitöründen yükselen kalp atışı sesi fonda duyulmaktadır (Resim 15). İlerleyen sahnelerde bu kalp atışı hızlanmakta ve bir aksilik yaşanmaktadır.

\section{Resim 15}

Gattaca, 1997. DVD. https://youtu.be/E50IdCTs89A

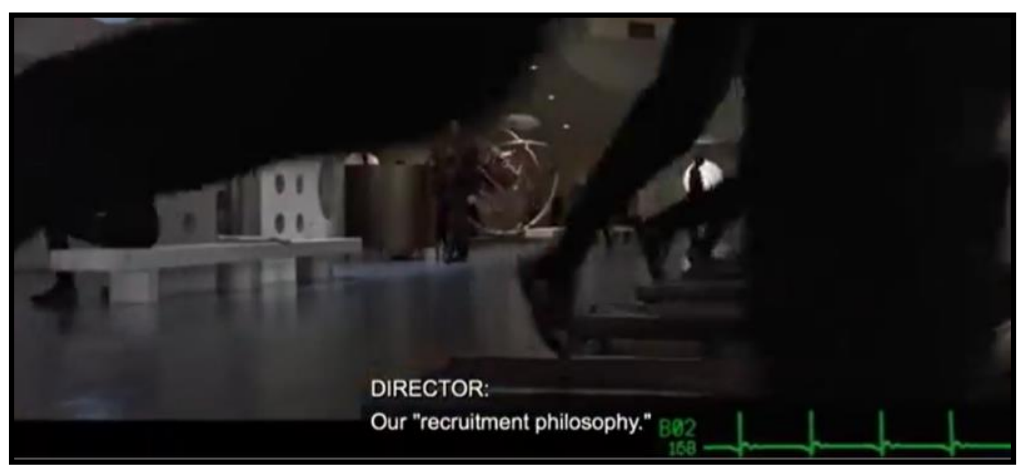

Üründe iki sessel düzgü de altyazıda verilmiş ancak biri görselleştirildiğinden alıcıya okuma yükü getirmeden anlama ve takip etme kolaylaştırılmıştır. 


\subsection{Beşinci Açılım: Alıcı Odaklılık, Duygu Aktarımı}

Beşinci açılım birçok farklı yöntemi kapsar. Amaç ise alıcı odaklı bir yaklaşımla tasarım yapılmasıdır. Bu bağlamda verilecek örneklerde altyazının bir duyguyu perçinlemek, bir ortamı betimlemek üzere tasarlanmasından söz edilebilir.

Duyguları perçinleyen altyazılara en klasik örnekler şarkı videolarına gömülen güftelerden verilebilir (Resim 16).

\section{Resim 16}

Creative subtitles for music videos. https://youtu.be/nCTIQ1_zv8Y

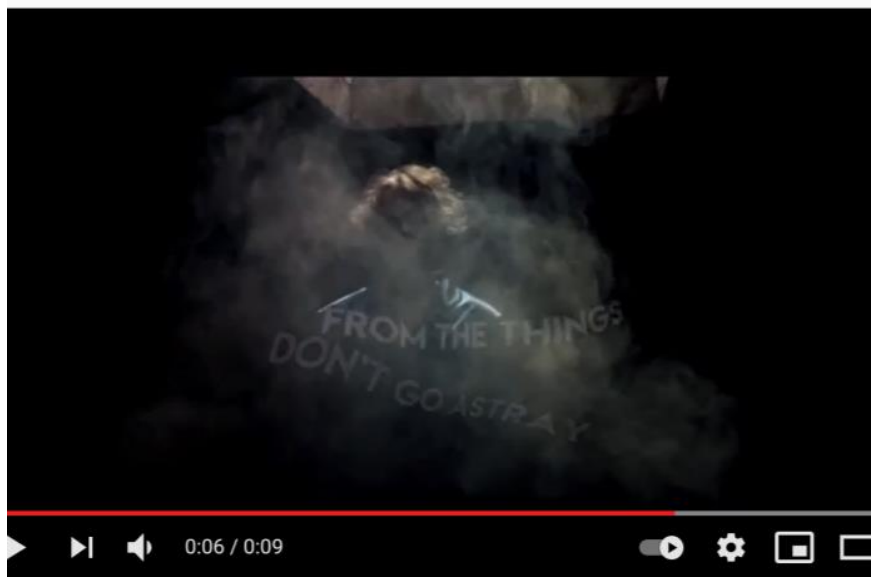

Ancak, bu örneklere ek olarak korku filmlerinde de çarpıcı açılımlar bulunabilmektedir. Night Watch filminden bir sahnede çocuk karakterin suyun altında duyduğu ve meşum tınıları olan ses tehlikeyi çağrıştıracak şekilde kırmızı altyazı ile iletilmiştir (Resim 17).

\section{Resim 17}

Night Watch (2004). https://vimeo.com/283470586

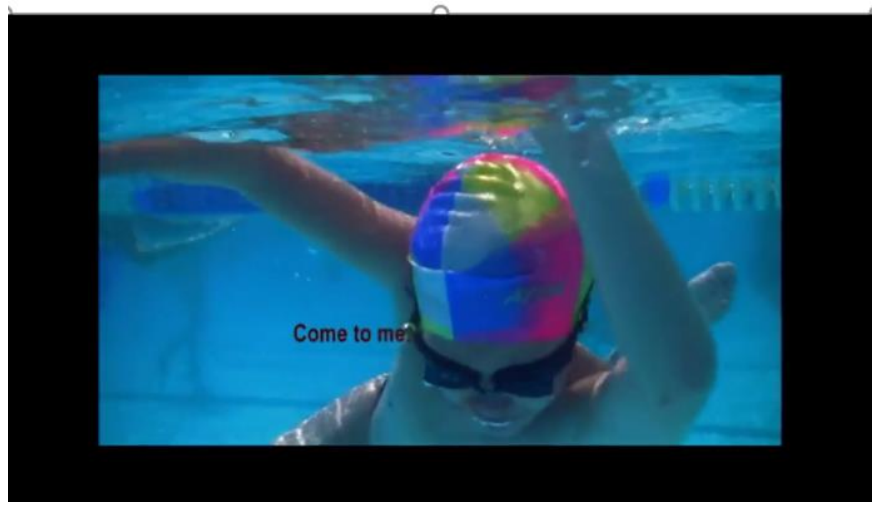


Altyazı Çevirisinde Teknoloji Destekli Yaratıcılık Açılımı*

Ancak burnu kanayan bu çocuk suyun yüzeyine çıktığında burnundan akan kanla birleşen altyazı suda dağılmış ve böylece burun kanaması sesle görsel bir efektle bağlantılandırılmıştır (Resim 18).

\section{Resim 18}

Night Watch (2004). https://vimeo.com/283470586

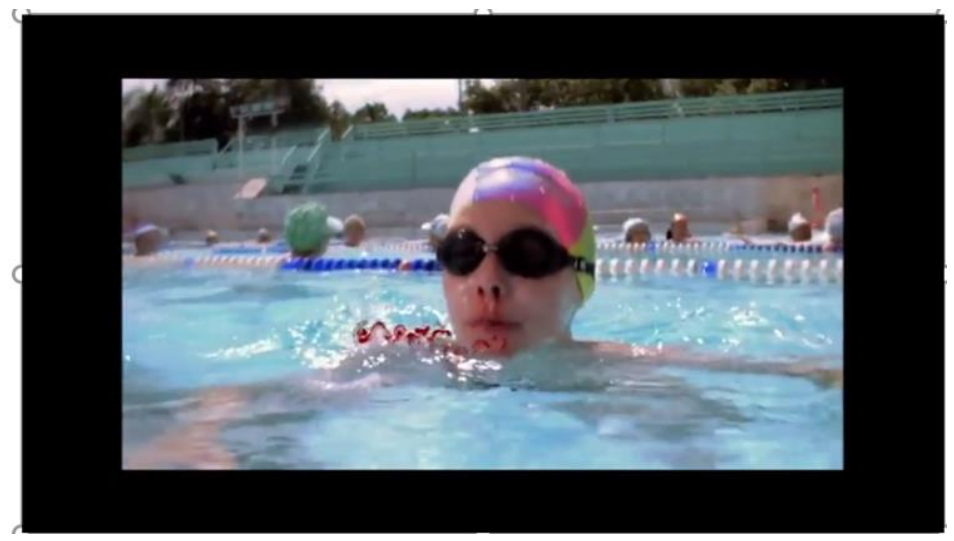

Görselle işitselin bütünleşik tasarımını içeren bu örneğin altyazı çevirisinde uygulaması ise oldukça zor olabilmektedir. Burada korku duygusu ön planda tutularak tasarım düşünülmüştür.

Yine korku duygusuna örnek vermek gerekirse, bu sefer de Resim 19'da yansıtılan Rocio Varela'nın The Conjuring 2 adlı filme yaptığı İspanyolca altyazı çevirisi örnek verilebilir. Bir ruhun musallat olduğu bir evde bu ruhu defetmeye çalışan birinin söz konusu ruh ile iletişiminin anlatıldığı sahnede iki 'karakter' (adam ve ruh) için farklı altyazı türleri kullanılmakla kalınmamış, aynı zamanda ruh için seçilen altyazı sunumu atipik bir yazı türü olduğundan, bu dünyadan olmayan bir varlığa işaret edilmiştir.

\section{Resim 19}

The Conjuring. https://vimeo.com/283470586

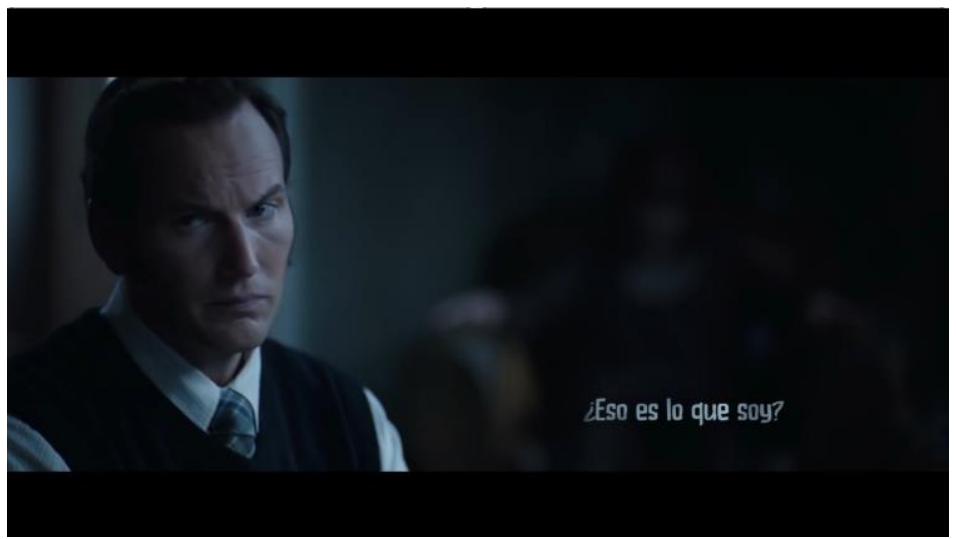


Ruhun, insan sesine benzemeyen, ürkütücü, yankılanan sesi âdeta görselleştirilmiştir.

Ortamdaki etkileşimi betimlemek için tasarlanan altyazılardan da söz edilebilir. Aşağıda verilen örnekte iki insanın (iki arkadaşın) karşılıklı hoş ve boş sohbetlerini betimlemek üzere altyazıların yerleştirimi değiştirilmiştir (Resim 20).

\section{Resim 20}

When Harry Met Sally (1989). https://vimeo.com/283470586

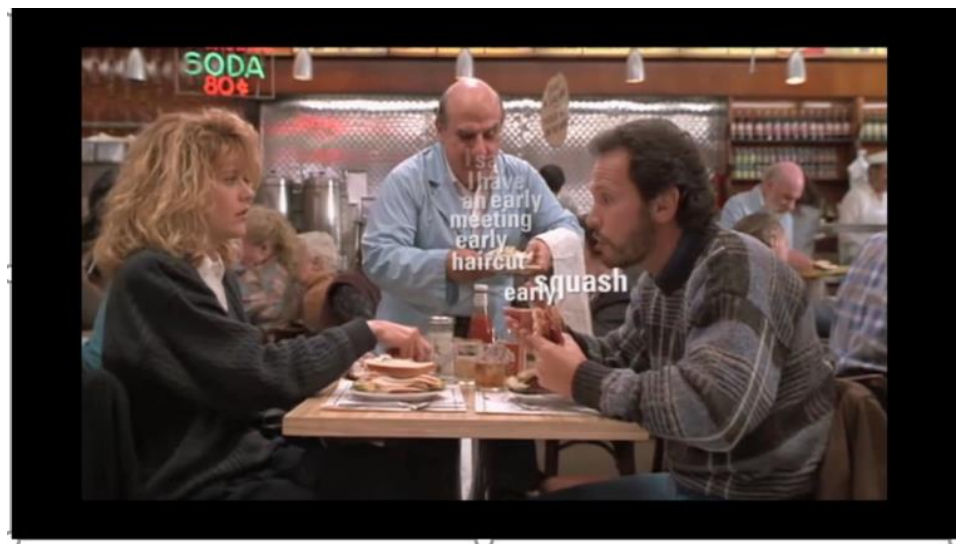

Altyazının görseli engellemeyecek şekilde ve sesin geldiği yönün ve şeklinin anlaşılabilecek biçimde yerleştirimi günümüzde altyazı çevirisi uygulamalarında sıkça görülen bir olgudur, yeni de değildir.

BBC'nin altyazı çevirisi kılavuzunda buna adanan bölümde, aşağıda örneklendiği şekilde bu yerleştirimlerin nedenleri de açıklanmıştır.

\section{Resim 21}

BBC. Subtitle Guidelines https://bbc.github.io/subtitle-guidelines/
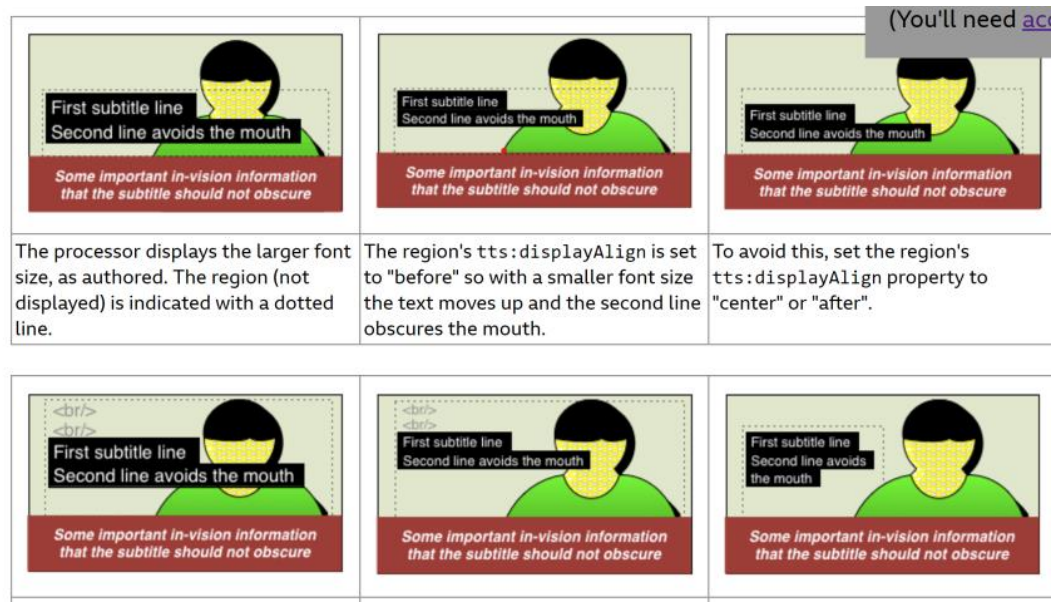
Bu temel tasarımlara ek olarak sesin geldiği yön sesin kaynağı kişinin altına altyazı yerleştirilmesi uygulaması da yeni değildir.

\section{Resim 22}

Sherlock Holmes. (2009). https://vimeo.com/283470586

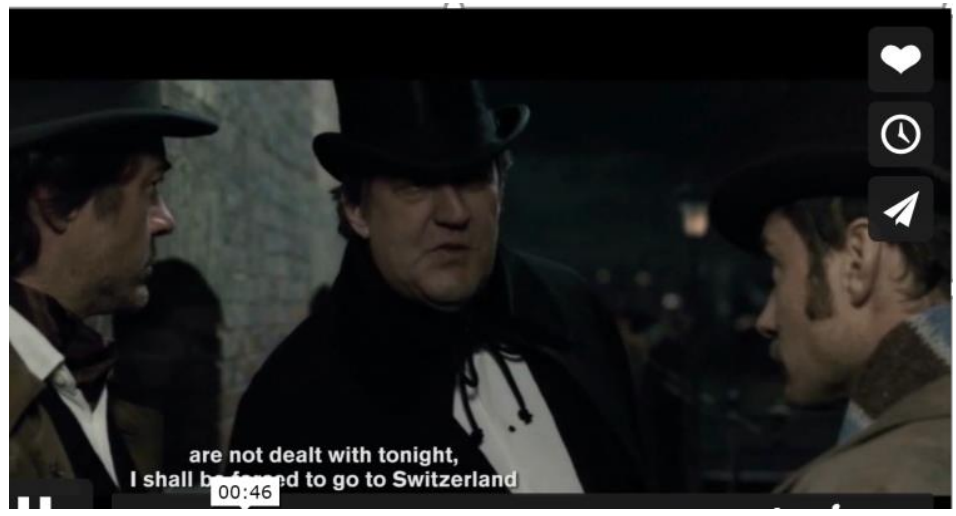

Wendy Fox tarafından altyazısı tasarlanan Sherlock Holmes (2009) filminden yukarıda verilen örnekte (Resim 22) Mycroft karakterinin repliği karakterin altına yerleştirilmiştir. Ancak ilerleyen sahnelerde bu altyazı karakteri ekranda takip etmiş (Resim 23) hatta karakter uzaklaştıkça ve sesi daha az duyulmaya başlandığında küçülmüş ve silikleşmiştir (Resim 24).

\section{Resim 23}

Sherlock Holmes. (2009). https://vimeo.com/283470586

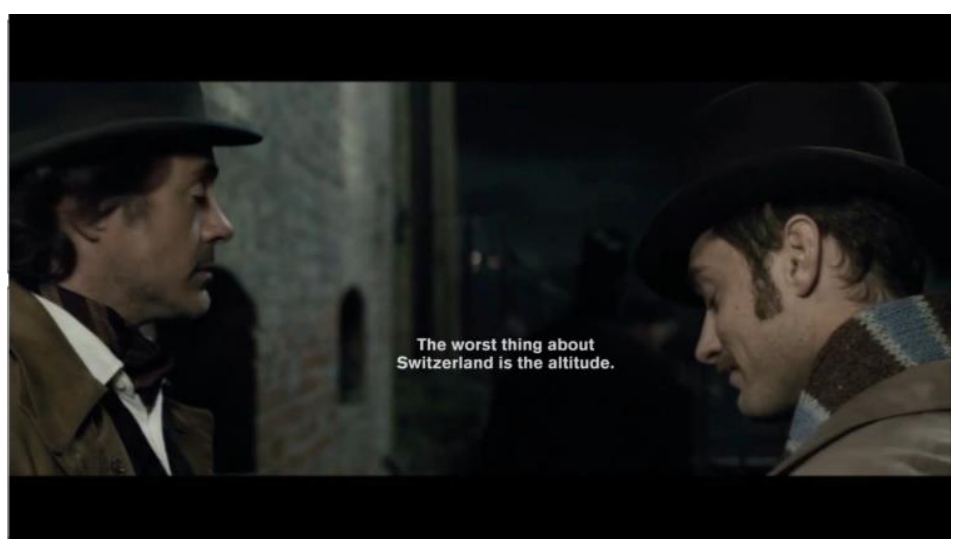




\section{Resim 24}

Sherlock Holmes. (2009). https://vimeo.com/283470586

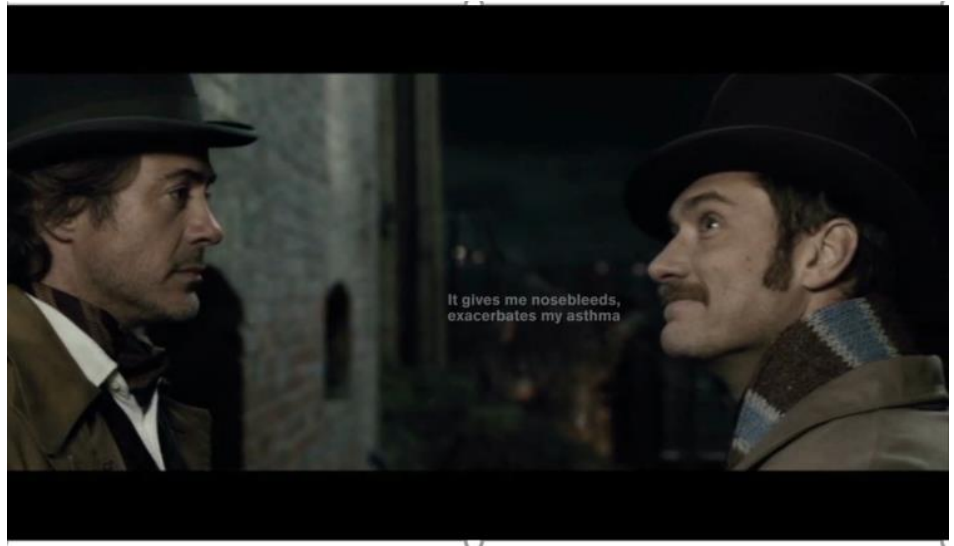

\section{Yorum / Tartışma}

Çalışmanın bulgular bölümünde internetten kamuya açık örneklerin derlemesinden oluşturulan bütünceden hareketle, yaratıcı yenilikçi açılıma dair birkaç farklı konu gündeme gelmektedir.

Birincisi, bugünün yaratıcı yenilikçi altyazı çevirisi açılımı altyazı çevirisi ilk yapıldığı günlerden beri kısıtlı doğası gereği çeviri zorluğu olarak nitelendirilen konulara alternatifler sunmaktadır. Şimdiye kadar sessel ögeden algıladığımız ancak yazı ile sunulan altyazıya yansıtamadığımız veya ancak parantezler kullanarak ve betimleyerek yansıttığımız unsurlar artık farklı olanaklarla yansıtılabilmektedir. Sesin geldiği yeri betimlemek için açtığımız parantezler ve açıklamaların yerini altyazıda yapılan tasarımla yansıtımı alabilmektedir.

Ayrıca, uzamsal kısıttan dolayı kimi zaman ürünün anlamlanabilmesi için bir işitsel girdi veya düzgünün feda edilmesi yerine iki işitsel düzgüyü, birini yazıyla birini görselle, sunabilme olanağına sahibiz. Buna ek olarak, işitsel düzgüden edinilen kaynakta amaçlanan duygunun yansıtımında parantez içinde verilen (korkutucu ses) gibi belirsiz açıklamalar yerine daha yaratıcı açılımlar sunulabilmektedir. Bir karakterin bir repliğinin sesletiminden çağrışım yapan bilgi altyazıda yansıtılabildiği gibi, algılamasını yansıtan bilgi de yansıtılabilmektedir. Seslerin gücünü (yükseklik, fısıltı vb) yansıtmak için olanaklar bulunmaktadır.

Temel hatlarıyla bakıldığında, aslında bütün örneklerde açıklanan ve yukarıda değinilen ögeler altyazı çevirisinin zaten içsel birer parçasıdır. Bugüne kadar altyazı çevirisi yapan çevirmenler bu unsurları bazı yöntemlerle ve yaklaşımlarla altyazı çevirilerine dâhil etmeye çalışmışlardır. Altyazıda tasarım yeni bir olgu değildir. Diyaloglarla karakter isimlerini, dış sesleri, ek bilgileri eğik yazı ile, tümü büyük harf ile, ayrı satırda kalın yazıyla vermeye başladığımız günden, hatta her repliğin başına tire koyarak konuşmacıları ayırt ettiğimiz günden bu yana altyazı çevirmenleri zaten tasarım 
yapmaktadırlar. Ayrıntılı altyazıda alımlamayı düşünmeye başladığımız zamandan bu yana da çabalarımız yoğunlaşmıştır.

Altyazı çevirisinin ürüne bir eklenti olduğunu gizlemek istercesine ürünle bütünleşik sunmak yaklaşımı da yeni değildir. Bu açıdan bakıldığında yeni olan tek şey aslında tüm bunları gerçekleştirebilmek ile bize teknolojinin sunduğu olanaklardır. Bir de tabii ki işveren ve yapımcıların altyazı çevirisinin önemi (özellikle erişim için yapılan türlerinin önemi) hakkında bilinçlenmesidir. Dolayısıyla, bu açılımlardan hiçbiri özünde yeni bir olguya işaret etmemekte, eski konulara yeni çözümler üretilmesini sağlamaktadır. Bu bağlamda da bu tür bir yaklaşımı altyazı çevirmeninin işinin bir parçası olarak görmeyecek meslektaşlar ve araştırmacılar olacağını hatırlamak gerekir. Ancak, tasarım unsuru altyazı çevirisinin hep içsel bir parçası olmuştur, yükün önemi ve etkinliği değişmiştir.

Yukarıda sözü edilen uygulamaların ne kadar yaygınlaşacağı ise çevirmenlerin evrimine, alıcıların taleplerine ve memnuniyetlerine ve işverenlerin olanak ve isteklerine göre değişecektir.

\section{Sonuç}

Sonuç olarak,

- teknolojinin evrilmesi,

- birçok kişinin belli yazılım ve bilgisayar programlarına ücretli veya ücretsiz olarak erişebilmesi ve altyazı çevirisinin yoğunlukla bu çeviri araçları üzerinden üretilmeye başlanması,

- Sağır ve işitme engellilere yönelik altyazı çevirisinin yaygınlaşmasının belli çeviri zorluklarının (kısıtlarının) altının çizilmesine neden olması,

- görsel-işitsel ürünlerin sadece analog kanallardan değil dijital platformlardan, internet üzerinden ve benzeri yöntemlerle iletilmesinin yaygınlaşması,

- tüm ortamlardaki kanalların ve görsel-işitsel üreticilerinin en yaygın kitlelere en kaliteli şekilde erişim sağlamak ve rekabet edebilmek için altyazı çevirisine daha fazla önem vermesi,

- ç̧ok ilgi çekici yaratıcı altyazı çevirisi örneklerinin çevirmenlere sunulması ve incelenmesi,

- farklı disiplinlerden araştırmacıların yaratıcı altyazı çevirisi olgusuna odaklanması,

ve daha birçok nedenden dolayı, altyazı çevirisi edimi sürekli evrilmektedir ve evrilmeye devam edecektir. Bu bağlamda da kaliteli ürünler verilmesi için, görsel iletişim ve tasarım bilgileri ile donatılmış görsel-işitsel ürünü düzgülerine ayırarak ve bütünleşik olarak irdeleyebilen çevirmenlerin hem teknolojileri takip etmeleri hem de çok disiplinli bir bakış açısıyla yeniliklere açık olarak eğitilmesi önem kazanmaktadır. 
Çalışmada sözü edilen ve yaratıcı açılım olarak betimlenen olgunun ne kadarının yaygınlaşacağı ne kadarının ise ileride birkaç ödüllü filmde görüleceği bilinmemektedir. Aynı şekilde kaç çevirmenin beceri setlerini genişleterek ve ek uğraşla bu yenilikçi açılımları benimseyeceği de öngörülemez. Piyasa gerçekleri, maddi konular, toplumsal açılımlarla ilgili konularda çevirmenler tarafları bilinçlendiren, yeni açılımları anlatan ve/veya savunan aktörler olabilirler. Ancak, araştırmacıların ve eğitimcilerin bu bağlamdaki sorumlulukları farklılık göstermektedir. Bu yenilikçi açılımlarla ortaya konulan ürünlerin alımlama çalışmalarını yapmak, alıcı kitleler ile çalışarak çevirmene çok cazip gelen bu açılımların ne oranda etkili olduğunu veya benimseneceğini tespit etmek araştırmacıların işi olacaktır.

Ayrıca, çalışma boyunca da vurgulandığı gibi bu açılıma bir tasarımcı gözünden bakarak (puntonun büyütülmesi, yazı stilinin değiştirilmesi, altyazının yerleştirimi vb.) veya teknik bir algıyla olguya bakarak (altyazılar kaynakta işlenmiş, entegre edilmiş, sonradan eklenmiş vb.) veya teknoloji kısıtları üzerinden bakarak (program özellikleri, kanal altyapılar vb.) betimleyen çalışmalar yerine çeviribilim açısından olguya bakan çalışmalar yürütmek önemli verilere gebe olabilecektir. Altyazı çevirisindeki olasılıklar hakkında alan uzmanlarını düşündüreceği gibi yeni eğitim yaklaşımlarının benimsenmesine de önayak olabilecektir.

\section{Kaynakça}

ABC. (2010). Industry guidelines on captioning television programs. www.abc.net.au/mediawatch transcripts/1105 freetvguidelines.pdf.

Albertini, J. \& Mayer, C. (2011). Using miscue analysis to assess comprehension in deaf college readers. Journal of Deaf Studies and Deaf Education, 16, 35-46. https://doi.org/doi:10.1093/deafed/enq017.

Baker, R. G., Lambourne, A. \& Rowston, G. (1984). Handbook for television subtitlers. Independent Broadcasting Authority.

BBC. (2018). BBC subtitle guidelines. The British Broadcasting Corporation. http://bbc .github.io/ subtitleguidelines/.

Black, S. (2020). Could integrated subtitles benefit young viewers? Children's reception of standard and integrated subtitles: a mixed methods approach using eye tracking, Perspectives. https://doi.org/10.1080/0907676X.2020.1849324

Brewer, E., Selfe, C. \& Yergeau, M. (2014). Creating a culture of access in composition studies. Composition Studies, 42(2), 151-154.

Brown, A., Jones, R., \& Crabb M. (2015) Dynamic subtitles: The user experience. D. Geerts, L. De Marez \& C. Pauwels (Eds.), Proceedings of the ACMinternational conference on interactive experiences for TV and online video (ss. 103-112). Association for Computing Machinery. https://dl.acm.org/doi/proceedings/10.1145/2932206

Butler, J. (2016). Where access meets multimodality: The case of ASL music videos. Kairos, 21(1).

Butler, J. (2017). Creating a (deaf)space for the fluidity of captions in video compositions. Conference on College Composition and Communication. NCTE. 
Chiaro, D. (2009). Issues in audiovisual translation. J. Munday (Ed.), The Routledge companion to translation studies (ss. 141-165). Routledge.

Delabastita, D. (1989). Translation and mass-communication: Film and TV translation as evidence of cultural dynamics. Babel, 35(4), 193-218.

Diaz-Cintas J., Matamala, A. \& Neves, J. (Eds.) (2010). New insights into audiovisual translation and media accessibility. Rodopi.

Diaz-Cintas, J. \& Remael, A. (2009). Audiovisaul translation: Subtitling. St Jerome Publishing.

Díaz Cintas, J. (2013). The technology turn in subtitling. M. Thelen \& B. Lewandowska-Tomaszczyk (Eds.), Translation and Meaning. Part 9 (ss. 119-132). Zuyd University of Applied Sciences.

Doherty, S. \& Kruger, J.-L. (2018). The development of eye tracking in empirical research on subtitling and captioning. J. Sita, T. Dwyer, S. Redmond, \& C. Perkins (Eds.), Seeing into Screens (ss. 46-64). Bloomsbury.

Ehrlich, S. F. \& Rayner, K. (1981). Contextual 20 effects on word perception and eye movements during reading. Journal of Verbal Learning and Verbal Behavior, 20, 641-655.

Hong, R., Wang, M., Xu, M., Yan, S. \& Chua, T.-S. (2010). Dynamic captioning: Video accessibility enhancement for hearing impairment. Proceedings of ACM Multimedia Conference. ACM.

Jankowska, A. \& Szarkowska, A. (2015). New points of view on audiovisual translation and media accessibility. Peter Lang.

Kruger, J.-L. \& Steyn, F. (2014). Subtitles and eye tracking: Reading and performance. Reading Research Quarterly, 49(1), 105-120. https://doi.org/10.1002/rrq.59.

Kruger, J.-L., Szarkowska, A. \& Krejtz, I. (2015). Subtitles on the moving image: an overview of eye tracking studies. Refractory, 25, 1-14.

Lazar, J. \& Stein, M. A. (2017) Introduction. Lazar, J., Stein, M. A. (Eds.). Disability, human rights, and information technology (ss. 1-10). University of Pennsylvania Press.

Lee, J., Jun, S., Jodi, F. \& Hudson, S. E. (2006). Using kinetic typography to convey emotion in textbased interpersonal communication. Proceedings of the 6th Conference on Designing Interactive Systems. ACM.

McClarty, R. (2012). Towards a multidisciplinary approach in creative subtitling. MonTI, 4, 133153.

Media Access Australia. (2012). Captioning Guidelines. https://mediaaccess.org.au/practicalwebaccessibility/ media/caption-guidelines

Möhnle, M. (2020, 16 Nisan). Creative subtitles - design and mechanics. IRT. https://lab.irt.de/creative-subtitles-design-and-mechanics/

Neves, J. (2008). Training in subtitling for the d/Deaf and the hard-of-hearing. J. Díaz Cintas (Ed.), The didactics of audiovisual translation (ss. 171-. 189). John Benjamins.

Okyayuz, A. Ş. (2016). Altyazı çevirisi. Siyasal Kitabevi.

Okyayuz, A.Ş. (2019). Görsel-işitsel çeviri ve engelsiz erişim. Siyasal Kitabevi.

Okyayuz, A. Ş. \& Kaya, M. (2017a). Görsel-işitsel çeviri eğitimi. Siyasal Kitabevi. 
Okyayuz, A. Ş. \& Kaya, M. (2017b). Çevirmenlik ve yaratıcılık. Frankofoni: Fransız Dili ve Edebiyatı inceleme ve Araştırmaları Ortak Kitabı, 30, 317-339.

Perego, E. (2008a). Subtitles and line-breaks: Towards improved readability. D. Chiaro, C. Heiss, \& C. Bucaria (Eds.), Between Text and Image: Updating research in screen translation, (ss. 211-223). John Benjamins. https://doi.org /10.1075/btl.78.21per.

Perego, E. (2008b). What would we read best? Hypotheses and suggestions for the location of line breaks in film subtitles. The Sign Language Translator and Interpreter, 2(1), 35-63.

Perego, E. (2016). Gains and losses of watching audio described films for sighted viewers. Target, 28(3), 424-444.

Persson, H., Åhman, H., Yngling, A. A. \& Gulliksen, J. (2015). Universal design, inclusive design, accessible design, design for all: different concepts - one goal? On the concept of accessibility - historical, methodological and philosophical aspects. Universal Access in the Information Society, 14, 505-526.

Rashid, R., Vy, Q., Hunt, R. \& Fels D. I. (2008). Dancing with Words: Using Animated Text for Captioning. International Journal of Human-Computer Interaction, 24(5), 505-19.

Rawsthorn, A. (2007, 27 Mayıs). The director Timur Bekmambetov turns film subtitling into an art. New York Times. http://www.nytimes.com/2007/05/25/style/25ihtdesign28.1.5866427.html?pagewanted=all\&_r=0.

Romero-Fresco, P. (2011). Subtitling through speech recognition: Respeaking. Routledge.

Romero-Fresco, P. (2013). Accessible filmmaking: Joining the dots between audiovisual translation, accessibility and filmmaking. The Journal of Specialised Translation, 20, 201223.

Romero-Fresco, P. (2019) Accessible Filmmaking: Integrating translation and accessibility into the filmmaking process. Routledge

Rosenberg, G. (2007, 15 Mayıs). Rethinking the art of subtitles. Time. http://content.time.com/time/arts/article/0,8599,1621155,00.html.

Strapparava, C., Valitutti, A. \& Stock, O. (2007). Dances with words. Proceedings from 20th International Joint Conference on Artificial Intelligence. ACM.

Vy, Q. V., Mori, J. A., Fourney, D. W., \& Fels, D. I. (2008). EnACT: A software tool for creating animated text captions. Klaus Miesenberger, Joachim Klaus, Wolfgang Zagler, \& Arthur Karshmer (Eds.), Proceedings from: Computers Helping People With Special Needs: 11th International Conference. Springer.

Vy, Q. V. \& Fels, D. I. (2009). Using avatars for improving speaker identification in captioning. Tom Gross vd. (Eds.), INTERACT 2009, Part II, LNCS 572 (ss. 916-919). International Federation for Information Processing.

Vy, Q. V. (2012). Enhanced captioning: Speaker identification using graphical and text-based identifiers [Yayımlanmamış yüksek lisans tezi]. Ryerson University. http://digitalcommons.ryerson.ca/dissertations/1702/.

Zdenek, S. (2007). Just roll your mouse over me: Designing virtual women for customer service on the web. Technical Communication Quarterly, 16(4), 397-430. 
Zdenek, S. (2011). Which sounds are significant? Towards a rhetoric of closed captioning. Disability Studies Quarterly, 31(3), 74-97. https://dsq-sds.org/article/view/1667/1604

Zdenek, S. (2014). More than mere transcription: Closed captioning as an artful practice. User Experience Magazine 14(1). http://www.usabilityprofessionals.org/uxmagazine/morethan-mere-transcription/.

Zdenek, S. (2015). Reading sounds: Closed-captioned media and popular culture. The University of Chicago Press.

Zdenek, S. (2016). Cripping closed captioning: Experiments with type, icons, and dynamic effects. Sweetland Digital Rhetoric Collaborative. Blog Carnival 9. http://www.digitalrhetoriccollaborative.org/2016/07/26/cripping-closed-captioningexperiments-with-type-icons-and-dynamic-effects/

Zdenek, S. (2018a). Designing captions: Disruptive experiments with typography, color, icons, and effects. Kairos: A Journal of Rhetoric, Technology, and Pedagogy, 23(1). http://kairos.technorhetoric.net/23.1/topoi/zdenek/index.html

Zdenek, S. (2018b). Guest editor's introduction: Reimagining disability and accessibility in technical and professional communication. Communication Design Quarterly, 6(4), 4-11.

Zdenek, S. (2020). Transforming access and inclusion in composition studies and technical communication. College English, 82(5), 536-544.

\section{Görsel-ișitsel kaynaklar:}

Gattaca (1997). https://www.imdb.com/title/tt0119177/?ref_=fn_al_tt_1

Night Watch (2004). https://www.imdb.com/title/tt0403358/

Sherlock (2010-2017). https://www.imdb.com/title/tt1475582/

Sherlock Holmes. (2009). https://www.imdb.com/title/tt0988045/

The 100 (2015). Blood Must Have Blood, Part 2. https://www.imdb.com/title/tt3986350/

The Conjuring 2 (2016). https://www.imdb.com/title/tt3065204/?ref_=fn_al_tt_1

Three Musketeers (2011). https://www.imdb.com/title/tt1509767/

When Harry Met Sally (1989). https://www.imdb.com/title/tt0098635/?ref_=nv_sr_srsg_0 